\title{
New species of Metynnis Cope, 1878 (Characiformes: Characidae) from the rio Paraguay basin, Mato Grosso State, Brazil
}

\author{
Carla S. Pavanelli ${ }^{1,2}$, Rafaela P. Ota ${ }^{2}$ and Paulo Petry ${ }^{3}$
}

A new species of Metynnis is described from the rio Cuiabá and rio Manso drainages, in the upper rio Paraguay basin, Mato Grosso State, Brazil. This laterally compressed species, which rarely exceeds $140 \mathrm{~mm}$ in SL, is readily distinguished from other members of the genus Metynnis by having 100-110 lateral-line scales, 48-56 rows of scales above the lateral line, 32-36 circumpeduncular scales, 22-24 gill rakers, 38 vertebrae, singular color pattern, and relatively smaller snout, width, and head length.

Uma nova espécie de Metynnis é descrita das drenagens dos rios Cuiabá e Manso, bacia do alto rio Paraguai, Estado do Mato Grosso, Brasil. Essa espécie de corpo comprimido lateralmente, que raramente excede os $140 \mathrm{~mm}$ de comprimento padrão, é prontamente diagnosticada dos outros membros do gênero Metynnis por possuir 100-110 escamas na linha lateral, 48-56 séries de escamas acima da linha lateral, 32-36 escamas circumpedunculares, 22-24 rastros branquiais, 38 vértebras, padrão de colorido distinto, e comprimento do focinho, largura e comprimento da cabeça relativamente menores.

Key words: Taxonomy, Neotropical, Ostariophysi, Freshwater, Serrasalminae.

\section{Introduction}

The genus Metynnis Cope, 1878 is widespread in South America, including the Amazon, Orinoco and Paraguay basins, rivers from northern and eastern Guyanas, and lower rio Paraná (Jégu, 2003). However, it recently invaded the upper rio Paraná basin after the construction of the Itaipu dam (Langeani et al., 2007). Currently, 14 valid species are recognized within the genus (Zarske \& Géry, 1999; 2008). The most recent phylogenetic study on the genus Metynnis suggests that it is included in the "piranha" clade with the genera Serrasalmus, Pristobrycon, Pygocentrus, Pygopristis and Catoprion (Ortí et al., 2008).

The upper rio Paraguay basin contains one of the largest floodplains in the world, the Pantanal, which consists of a wide sedimentary plain which extends from Central Brazil to Eastern Paraguay and Bolivia. The rio Cuiabá flows through two Brazilian States (Mato Grosso and Mato Grosso do Sul) and flows through the Pantanal into the rio Paraguay near the border between Brazil and Bolivia. One of the most important tributaries of the rio Cuiabá is the rio Manso, where a hydroelectric dam was built in late 1999. In the rio Paraguay basin Jégu \& Ingenito (2007) registered four species of Metynnis: M. hypsauchen (Müller \& Troschel, 1844), M. maculatus (Kner, 1858), M. mola Eigenmann \& Kennedy, 1903 and M. otuquensis Ahl, 1923. During sampling carried out by the Núcleo de Pesquisas em Limnolgia, Ictiologia e Aqüicultura (Nupélia), of the Universidade Estadual de Maringá, in the region of influence of the Manso Reservoir, specimens of a new species of Metynnis were caught. This species is described herein.

\section{Material and Methods}

Measurements were taken point-to-point with a caliper to the nearest $0.1 \mathrm{~mm}$, and counts under a stereomicroscope, both on the left side of the specimens whenever possible. Morphometrics were taken following Géry (1972), with the addition of three measurements: caudal-peduncle depth,

\footnotetext{
${ }^{1}$ Universidade Estadual de Maringá, Núcleo de Pesquisas em Limnologia, Ictiologia e Aqüicultura, Av. Colombo, 5790, 87020-900 Maringá, Paraná, Brazil. carlasp@nupelia.uem.br

${ }^{2}$ Universidade Estadual de Maringá, Programa de Pós-Graduação em Ecologia de Ambientes Aquáticos Continentais, Av. Colombo, 5790, 87020-900 Maringá, Paraná, Brazil.rafinhaota@yahoo.com.br

${ }^{3}$ Museum of Comparative Zoology, Harvard University, 26 Oxford St. Cambridge, MA 02138, United States of America; and The Nature Conservancy, South America Conservation Region. ppetry@oeb.harvard.edu; ppetry@tnc.org
} 
length of supraoccipital process, and distance between end of supraoccipital process and dorsal-fin origin. Morphometric data of the body are presented in proportions of the standard length (SL) and data of head structures are presented in proportions of the head length (HL). Meristic data followed Zarske \& Géry (1999). Vertebrae were counted in four x-rayed specimens (MZUSP 100626-holotype, NUP 2055 and MCZ 168058). In vertebral counts the fused $\mathrm{PU} 1+\mathrm{U} 1$ is considered a single bone, and the vertebrae incorporated into the Weberian apparatus are counted as four elements. Data presented in the diagnosis were obtained by comparative analysis of specimens (when available), original descriptions of all congeners and from the genus revision by Zarske \& Géry $(1999,2008)$. Therefore, ranges provided in the diagnosis have minimum and maximum values recorded by Zarske \& Géry $(1999,2008)$ for the type specimens. Institutional abbreviations are as listed at http://research.calacademy.org/ research/ichthyology/catalog/abtabr.html.

\section{Metynnis cuiaba, new species Figs. 1-5}

Metynnis maculatus.—Veríssimo et al., 2005: 4 [Brazil, Mato Grosso State, Manso Reservoir, upper rio Paraguay basin; check list].

Holotype. MZUSP 100626, 142.5 mm SL, Brazil, Mato Grosso State, Município de Barão de Melgaço and Santo Antônio do Leverger, baía Sinhá Mariana, rio Cuiabá, rio Paraguai basin, 16²0’20”S 5554’10”W, 22 May 2000, Nupélia.

Paratypes. All from Brazil, Mato Grosso State: MCZ 168058, 1, 111.6 mm SL, 21 Nov 2003; MCZ 168059, 1, 67.0 mm SL, 23 Jul 2002; MZUSP 100627, 6, 73.4-105.2 mm SL, 21 Sep 2003; NUP 2055, 2, 103.2-119.3 mm SL, 21 Nov 2003; NUP 2933, 1, 80.8 mm SL, 21 Jun 2003; NUP 3276, 1, 131.1 mm SL, 20 Nov 2003; NUP 4782, 5, 104.5-137.4 mm SL, 26 Jan 2001; NUP 5211, 1, 63.0 mm SL, 23 Jul 2002; NUP 5220, 1, 130.1 mm SL, 24 Apr 2000; NUP 5264, 2, 61.4-72.4 mm SL, 24 Jul 2002; NUP 5265, 1, 70.4 mm SL, 14 Aug 2002; NUP 5266, 1, 115.7 mm SL, 15 Dec 2002; NUP 5267, 1, 59.2 mm SL, 21 Jun 2003; NUP 5268, 1, 98.5 mm SL, 26 Jul 2003: same locality as the holotype. Município de Chapada dos Guimarães, Nobres and Barão de Melgaço: NUP 4983, 2, 50.6 mm SL, baía Tia Chica at rio Manso, rio Paraguay basin, 14'52'21's 5547'53”W, 20 Jul 1998; NUP 5213, 2, 64.9-72.2 mm SL, Manso Reservoir at rio Manso, rio Paraguay basin, 1452’22”S 5546’28”W, 15 Aug 2003.

Diagnosis. The new species is readily diagnosed from Metynnis fasciatus, M. guaporensis, M. hypsauchen, $M$. longipinnis, $M$. luna and $M$. orinocensis by its lower number of gill rakers (22-24 vs. 31-33 in $M$. fasciatus, 47-65 in $M$. guaporensis, 32-34 in M. hypsauchen, 30-33 in M. longipinnis, 48-56 in M. luna and 57-59 in M. orinocensis). From other congeners $M$. cuiaba can be diagnosed by the presence of 100-110 lateral-line scales (vs. 80-95 in M. lippincottianus, 117-127 in M. maculatus, and 115-125 in M. otuquensis); 4856 rows of scales above lateral line (vs. 62-68 in M. polystictus); one or two bifurcate spines in the ventral keel (vs. bifurcate spines covering most ventral keel in M. mola); dark blotches, with ill-defined contour, sometimes forming transversal bars in the flanks (vs. body without any blotches in M. altidorsalis and M. anisurus, and dark blotches with well-defined contour not forming transversal bars in M. argenteus). Metynnis cuiaba is also separated from $M$. argenteus by having 48-56 rows of scales above lateral line (vs. 62-68), 55-64 predorsal scales (vs. 67-72), and 32-36 circumpeduncular scales (vs. 26-28).

Description. Morphometric data presented in Table 1. Body deeply compressed, with rounded dorsal and ventral profiles. Highest body depth on vertical line passing through dorsal and pelvic fins origin. Predorsal distance longer than postdorsal. Dorsal profile of body convex from snout to dorsal-fin origin; dorsal fin with straight base, very inclined posteriorly; preadipose profile obliquely straight, slightly convex from adipose-fin origin to caudal-fin origin. Ventral profile convex, with series of 32-36 simple spines in ventral keel (mean $=34.8 ; 23-26+9-10)$, followed by one or two bifurcate spines, never surpassing anus. Caudal peduncle short, much deeper than longer, with dorsal and ventral margins straight or slightly concave. Dorsal profile of head concave. Ventral profile of the head oblique, almost convex. Snout roundish in lateral view. Eye lateral. Mouth terminal with molariform teeth. Inner premaxillary row with five teeth, outer with two. Dentary with four anterior teeth. Branchial membranes joint together and free of isthmus. Twenty two to 24 (mean $=22.7 ; 10+12-14)$ tubercular, short and thick gill rakers; cerato- and epibranchials similarly long.

Dorsal-fin rays i,15-17 (mean = 16.5); not reaching adiposefin origin when adpressed; one forwarded spine anterior to dorsal-fin origin. Dorsal-fin origin at mid-body or a little behind of vertical through pelvic-fin origin; dorsal-fin margin truncate. Adipose fin well-developed; its base longer than distance between dorsal-fin insertion and adipose-fin origin; adiposefin origin before vertical through middle anal fin. Pectoral-fin rays i,10-13 (mean =12.6); its distal margin convex, with anterior rays longer, forming roundish edge, not reaching vertical through dorsal-fin origin when adpressed. Pelvic-fin rays i,67 (mean $=6.7$ ); its distal margin convex, with anterior rays slightly elongate, forming roundish edge, not reaching vertical through anal-fin origin when adpressed. Anal-fin rays iii,3236 (mean = 34.1); with sexually dimorphic distal margin (see Fig. 3); unbranched rays well-developed and joined in structure similar to spine. Caudal-fin rays vii,17 (9+8); its distal margin bifurcate, with both lobes of similar length.

Body completely covered by very small cycloid scales, somewhat irregularly arranged on predorsal region and more irregularly distributed on preanal region. Scales of caudal peduncle covering only base of caudal fin, not extending over its rays. Lateral line complete, with 100-110 (mean = 103.5) perforated scales, with first four or five bigger than remaining; 48-56 $($ mean $=53.0)$ rows of scales above, and 53-60 (mean = 55.2 ) below lateral line. Fifty five to $64($ mean $=59.6)$ predorsal scales. Twenty four to $30($ mean $=26.4)$ rows of scales between 


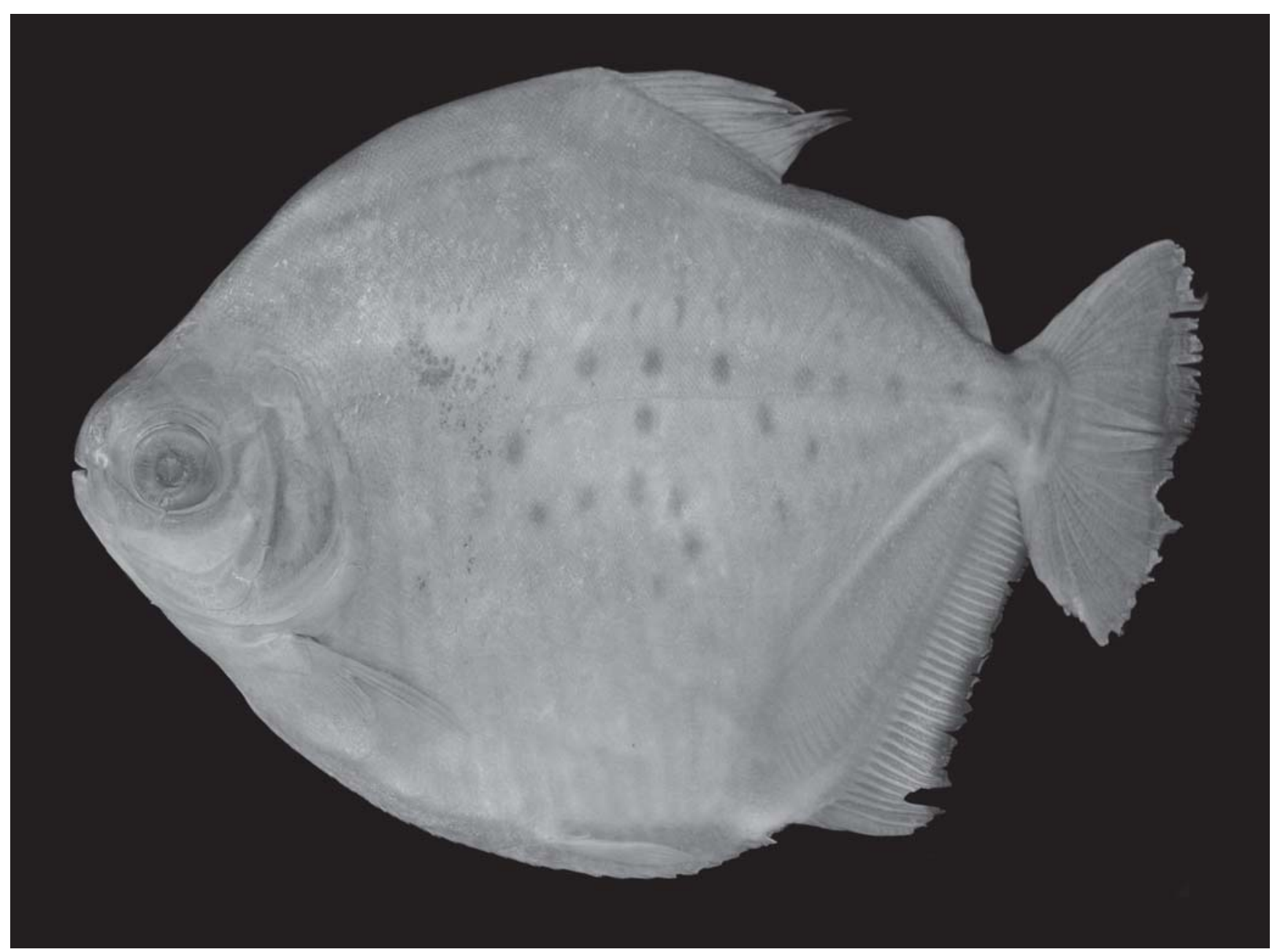

Fig. 1. Metynnis cuiaba, holotype, MZUSP 100626, 142.5 mm SL, female, baía Sinhá Mariana, rio Cuiabá drainage.

adipose-fin origin and lateral line. Twenty five to 31 (mean = 28.6) circumpeduncular rows of scales. Vertebrae $38(4+13+21)$.

Color in alcohol. Overall body background color brown, darker on head and dorsal portion of body. Body sides with numerous, roundish, dark, pupil sized spots, with illdefined contour, more concentrated at middle of body depth. Lateral spots sometimes coalesced and forming transversal bands (Fig. 2). Dark humeral blotch, with illdefined contour, behind opecular edge, above or on lateral line. Dorsal, adipose, pectoral, anal and caudal fins darkly pigmented, pigments more concentrated along its distal edge, forming narrow dark stripe. Anal fin of juveniles (less than $70.0 \mathrm{~mm}$ SL) with only a narrow dark margin. Pelvic fin without pigmentation.

Sexual dimorphism. Adult males of Metynnis cuiaba exhibit a lobule at the distal edge of the anal fin, and dorsal-fin rays are not elongated. Adult females have distal anal-fin margin somewhat straight and first dorsal-fin rays elongated, forming filaments apparently only during breeding period (Fig. 3).

Distribution. Metynnis cuiaba is known from the upper
Table 1. Morphometric data for Metynnis cuiaba $(\mathrm{n}=30)$, from the Cuiabá and Manso drainages, upper rio Paraguay basin. Mean includes the holotype.

\begin{tabular}{|c|c|c|c|c|}
\hline & Holotype & Range & Mean & SD \\
\hline Standard length (mm) & 142.5 & $50.6-142.5$ & & \\
\hline \multicolumn{5}{|c|}{ Percents of standard length } \\
\hline Head length & 29.0 & 26.9-30.8 & 28.6 & 0.89 \\
\hline Body depth & 81.8 & 72.0-86.9 & 80.8 & 5.50 \\
\hline Caudal-peduncle depth & 11.5 & 10.3-11.9 & 11.1 & 0.56 \\
\hline Predorsal length & 66.6 & $61.1-67.0$ & 64.8 & 2.85 \\
\hline Postdorsal length & 62.5 & 58.3-63.8 & 60.7 & 1.78 \\
\hline Prepelvic len & 52.9 & $50.8-$ & 53.3 & 1.28 \\
\hline Dorsal-fin length & 22.5 & 22.5 & 29.0 & 4.35 \\
\hline Pectol & 22.5 & 19. & 22.3 & 1.30 \\
\hline Pelvi & 3 & 14.3 & 15.8 & 1.32 \\
\hline Anal- & 12.6 & 12.3 & 14.6 & 1.82 \\
\hline Dorsa & 21.6 & 21.4-26.3 & 24.2 & 1.44 \\
\hline Adipos & 14.5 & $12.2-15.8$ & 14.0 & 1.05 \\
\hline Anal-fin base length & 42.3 & 40.1-47.9 & 44.1 & 2.68 \\
\hline Supraoccipital process to dorsal fin distance & 49.7 & $43.3-50.0$ & 46.9 & 2.18 \\
\hline Dorsal to adipose fin distance & 13.8 & $10.0-13.9$ & 11.6 & 1.26 \\
\hline cipital process length & 17.1 & $14.7-17.1$ & 16.1 & 0.67 \\
\hline Intero & 15.9 & $14.4-16.3$ & 15.2 & 0.47 \\
\hline Orbital diameter & 10.8 & $10.5-12.6$ & 11.4 & 0.55 \\
\hline Snout length & 8.7 & 8.0-8.9 & 8.6 & 0.21 \\
\hline \multicolumn{5}{|c|}{ Percents of head length } \\
\hline Intel & 54.9 & 50.1 & 53.0 & 1.80 \\
\hline Orb & 37.1 & 37.1-42.9 & 39.9 & 1.46 \\
\hline Snout length & 29.9 & 28.0-31.6 & 30.1 & 1.00 \\
\hline
\end{tabular}




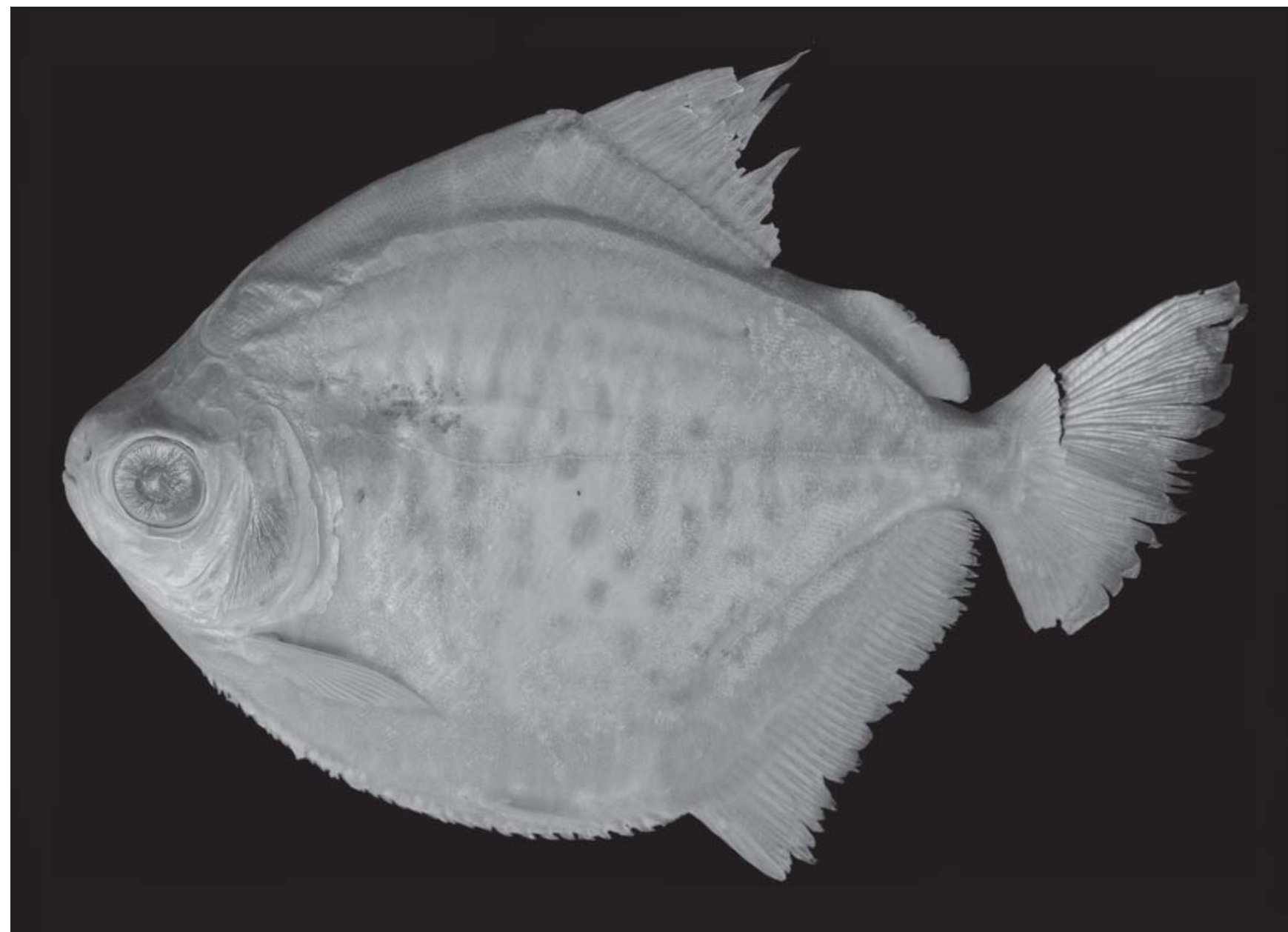

Fig. 2. Metynnis cuiaba, paratype, NUP 2055, 111.6 mm SL, female, baía Sinhá Mariana, rio Cuiabá drainage.

portions of rio Paraguai basin, in Cuiabá and Manso river drainages, including lakes (baías) in the Pantanal, Mato Grosso State, Central Brazil (Fig. 4).

Etymology. The species name, cuiaba, is given in reference to the type-locality of the new species, rio Cuiabá, tributary to rio Paraguai. A noun in apposition.

Remarks. Juvenile specimens (less than $70.0 \mathrm{~mm} \mathrm{SL}$ ) have a higher proportion ratio between body depth and SL, which diminishes during ontogenetic development (Fig. 5).

\section{Discussion}

The first comprehensive study on Metynnis was published by Ahl (1923), who recognized 18 nominal species. In the following decades, several of those species were synonymized in the revision of the genus by Gosline (1951), resulting in the recognition of only six valid species. However, according to Zarske \& Géry (1999), both supramentioned authors did not investigated type-specimens of all described taxa, neither considered the breeding period of those species, despite those species display an accentuated sexual dimorphism. Ontogenetic development was not evaluated either, resulting in the description of three different taxa based on juveniles, and both adult males and females of the same species (Zarske \& Géry, 1999). In addition, a still more serious problem is the small number of specimens analyzed by Ahl (1923), when revising the genus (36 specimens for 18 species).

Géry (1979) emphasized the requirement of a revision of that group, contesting the synonymy between $M$. fasciatus Ahl, 1931 and M. hypsauchen. Two decades later, Zarske \& Géry (1999) published a new revision of the genus including all unconsidered characters by previous authors. As result, they recognized 11 valid species, among them $M$. fasciatus and $M$. hypsauchen, and synonymyzed other 13 . From these, nine were described in Ahl's (1923) publication, besides other four: M. unimaculatus Steindachner, 1908, M. orbicularis (Steindachner, 1908), M. dungerni Ahl, 1923 and M. ehrhardti Ahl, 1927. As Zarske \& Géry (1999) analyzed only type specimens of described taxa and neglected to look at a more comprehensive sample with a wider geographic scope, they did not examine material of the species, described herein as M. cuiaba. This resulted in the recognition of only four species in the rio Paraguay basin 


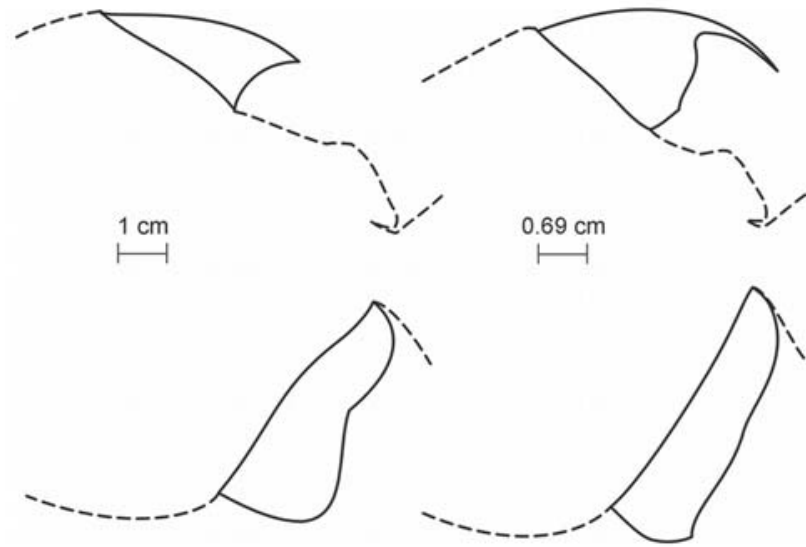

Fig. 3. Sexual dimorphism in Metynnis cuiaba. Left: NUP 3276, $131.1 \mathrm{~mm}$ SL, male; right: MZUSP 100627, $80.5 \mathrm{~mm}$ SL, female. Both collected at baía Sinhá Mariana, rio Cuiabá drainage.

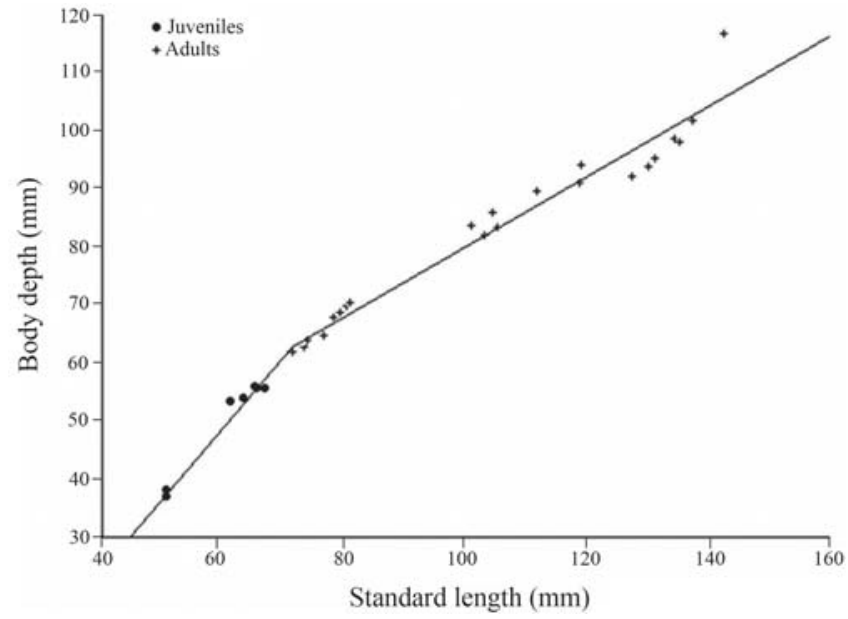

Fig. 5. Ratio between standard length and body depth in juveniles and adults of Metynnis cuiaba.

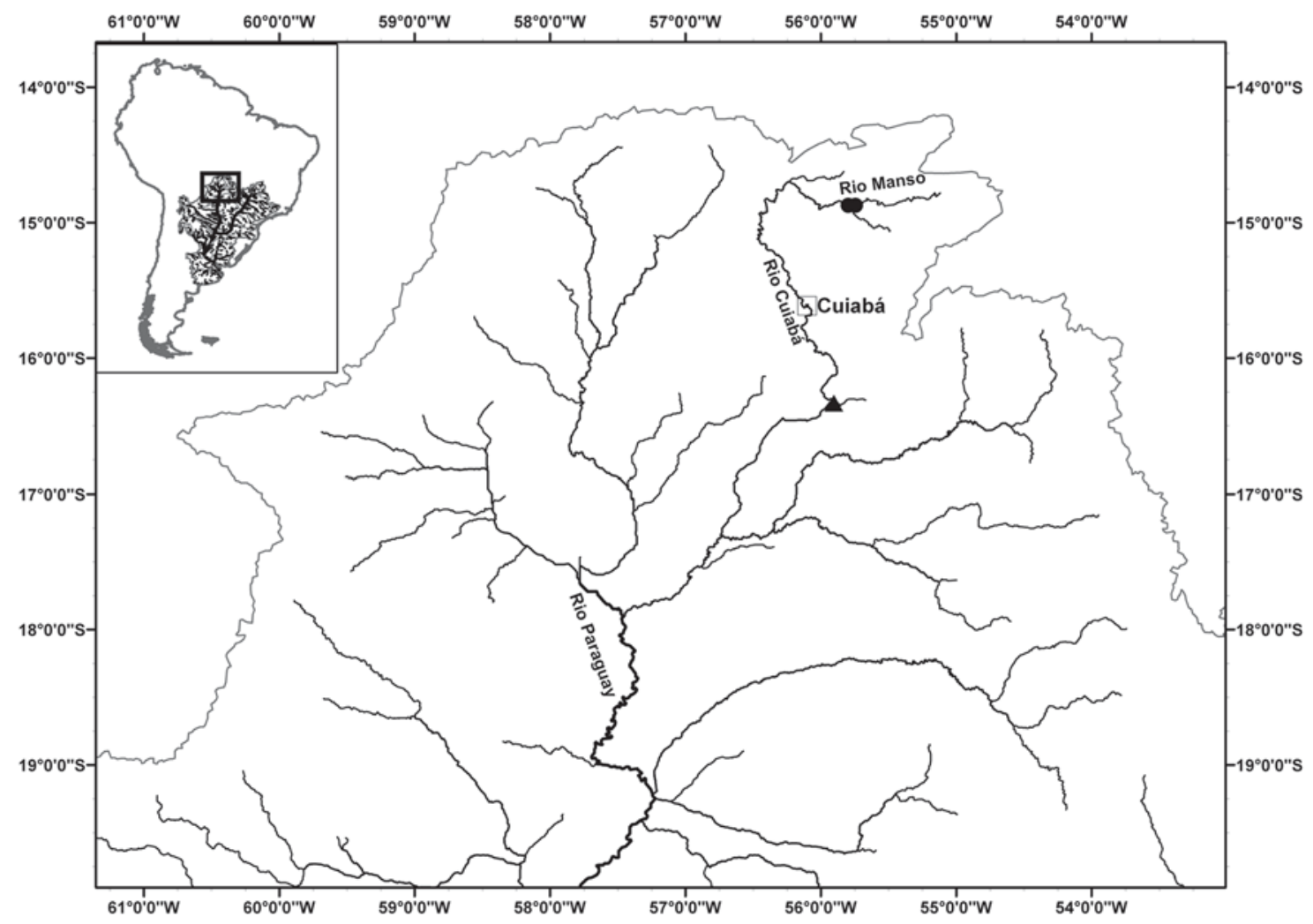

Fig. 4. Partial map of Brazil and adjoining countries showing collecting sites of Metynnis cuiaba. Asterisk = type locality. Dot $=$ distribution (symbols represent more than one collecting locality).

(M. hypsauchen, M. maculatus, M. mola and M. otuquensis), all already described.

Metynnis cuiaba is from the Pantanal, a very wide floodplain, located in the rio Paraguai basin, which has the rio Cuiabá as one of its main headwater rivers. Despite of its well known biodiversity richness and high degree of endemism, only M. mola and M. maculatus had been previously recorded in that basin.

Ontogenetic development was analyzed as well in the new species, and a pronounced allometry was observed. A higher body depth to SL ratio in juveniles is supposedly more related with avoiding predation when juvenile.

According to Veríssimo et al. (2005), the rio Manso bears many species in common with the typical fish fauna from the 
Pantanal and rio Paraguai, and amongst other 248 species caught and recorded during that project are Metynnis cuiaba and its congener M. mola. The other congener, M. maculatus, was identified only from previous collection specimens collected near the sampled region approximately 30 years ago (MZUSP 20429). The region influenced by the Manso Reservoir was sampled upstream to the Pantanal, including the rio Cuiabá and a great diversity of environments, such as headwaters, streams, rivers, lakes and the reservoir itself, situated along the rio Manso. It comprises a significant area, however relatively small when compared to the whole basin, thus $M$. maculatus might occur in environments which were not sampled by the survey carried out by Veríssimo et al. (2005).

Species of Metynnis have been studied for decades, however there are still misidentifications, mainly because of the high ontogenetic variability, the sexual dimorphism and the absence of identification keys, besides the existence of several nominal taxa of doubtful status. Perhaps further careful inventories in the rio Paraguai basin could reveal even additional new species of Metynnis. In spite of serrasalmin systematics are undergoing major revision and much remains to be done. Even the status of the family is still not a consensus. Some recent researchers still maintain the subfamily Serrasalminae (Jégu, 2003), while others recognize them as a distinct family, the Serrasalmidae (e.g. Calcagnotto et al., 2005). According to Freeman et al. (2007) future studies should include combined genetic data and careful documentation of specimens examined.

Material examined. All from Brazil. Metynnis altidorsalis: MCP 21045, 1, 72.5 mm SL, Pará State, ilha de São Miguel, rio Amazonas; MZUSP 6716, 5, 64.0-68.8 mm SL, Amazonas State, rio Negro close to Manaus. M. argenteus: MZUSP 37437, 3, 87.4-139.6 mm SL, Mato Grosso State, rio Guaporé, close to Vila Bela da Santíssima Trindade. M. fasciatus: MCP 20985, 1, 52.7 mm SL, Pará State, Santarém, rio Tapajós. $M$. hypsauchen: MCP 15107, 1, 90.0 mm SL and MCP 15127, 1, 72.5 mm SL, Pará State, Itaituba, rio Tapajós; MZUSP 20576, 2, 70.0-80.0 mm SL, Pará State, lago Jurunundéus at rio Capim, tributary to rio Guamá. $M$. cf. lippincottianus: NUP 4499, 1, 107.8 mm SL, Paraná State, Pato Bragado, Itaipu Reservoir at rio Paraná, 24 38’S 54 ²0’W; NUP 4522, 6, 66.3-76.3 mm SL, Paraná State, Diamante do Norte, Rosana Reservoir at rio Paranapanema, tributary to rio Paraná, 22³6’01”S 52 '52’02”W; NUP 4663, 2, 122.0-122.1 mm SL, Paraná State, São Miguel do Iguaçu, rio Ocoí, tributary to Itaipu Reservoir at rio Paraná, 2513’38”S 55¹3’29”W. M. luna: MZUSP 19388, 5, 72.8-83.5 mm SL, Roraima State, rio Mucajaí, tributary to rio Branco, close to Boa Vista. M. maculatus: MZUSP 20429, 6, 112.5-122.2 mm SL, Mato Grosso State, Barão de Melgaço, rio Piraim, branch of rio Cuiabá. M. mola: NUP 2873 3, 55.5-56.5 mm SL, Mato Grosso State, Barão de Melgaço and Santo Antônio de Leverger, baía Sinhá Mariana at rio Cuiabá, tributary to rio Paraguai, 16²0'20”'S 5554'10”W.

\section{Acknowledgements}

Thanks are due to H. Júlio Jr., E. Goulart and C. Zawadzki for critical reading the manuscript, O. Oyakawa and M. Lucena for loaning specimens, M. de Pinna and E. Baena for helping with x-rays, and G. Deprá for kindly helping with drawing of sexual dimorphism. Nupélia and Furnas Centrais Elétricas offered logistical support. This study was partially supported by grants from the CNPq (Conselho Nacional de Desenvolvimento Científico e Tecnológico) to CSP (Proc. n. 311975/2006-2) and RPO (Proc. n. 504053/2007-8).

\section{Literature Cited}

Ahl, E. 1923. Eine Revision de Characiniden-Gattung Metynnis. Ichthyologische Mitteilungen, 11(1): 15-31.

Calcagnotto, D., S. A. Schaefer \& R. DeSalle. 2005. Relationships among characiform fishes inferred from analysis of nuclear and mitochondrial gene sequences. Molecular Phylogenetics and Evolution, 36: 135-153.

Freeman, B., L. G. Nico, M. Osentoski, H. L. Jelks \& T. M. Collins. 2007. Molecular systematic of Serrasalmidae: Deciphering the identities of piranha species and unraveling their evolutionary histories. Zootaxa, 1484: 1-38.

Géry, J. 1972. Poissons Characoïdes des Guyanes. I Généralités. II. Famille des Serrasalmidae. Zoologische Verhandelingen, 122: 1250.

Géry, J. 1979. The Serrasalmidae (Pisces, Characoidei) from the Serra do Roncador, Mato Grosso, Brazil. Amazoniana, 6(4): 475-478.

Gosline, W. A. 1951. Notes on the characid fishes of the Subfamily Serrasalminae. Proceedings of the California Academy of Sciences, 27(2): 17-61.

Jégu, M. 2003. Subfamily Serrasalminae. Pp. 182-184. In: Reis, R. E., S. O. Kullander \& C. J. Ferraris Jr. (Eds.). Check list of the freshwater fishes of South and Central America. Porto Alegre, Edipucrs, 729p.

Jégu, M. \& L. F. S. Ingenito. 2007. Serrasalminae. Pp. 40-43. In: Buckup, P. A., N. A. Menezes \& M. S. Ghazzi (Eds.). Catálogo das espécies de peixes de água doce do Brasil. Rio de Janeiro, Museu Nacional, 195p.

Langeani, F., R. M. C. Castro, O. T. Oyakawa, O. A. Shibatta, C. S. Pavanelli \& L. Casatti. 2007. Diversidade da ictiofauna do alto rio Paraná: composição atual e perspectivas futuras. Biota Neotropica, 7(3): 1-17.

Ortí, G., A. Sivasundar, K. Dietz \& M. Jégu. 2008. Phylogeny of the Serrasalmidae (Characiformes) based on mitochondrial DNA sequences. Genetics and Molecular Biology, 31(1): 343-351.

Veríssimo, S., C. S. Pavanelli, H. A. Britski \& M. M. M. Moreira. 2005. Fishes from the Manso Reservoir region of influence, rio Paraguai basin, Mato Grosso State, Brazil. Check List, 1(1): 1-9.

Zarske, A. \& J. Géry. 1999. Revision der neotropischen Gattung Metynnis Cope, 1878. Evaluation der Typusexemplare der nominellen Arten (Teleostei: Characiformes: Serrasalmidae). Zoologische Abhandlungen Staatliches Museum für Tierkunde Dresden, 50(13): 169-216.

Zarske, A. \& J. Géry. 2008. Revision der neotropischen Gattung Metynnis Cope, 1878. Beschreibung zweier neuer Arten und zum Status von Metynnis goeldii Eigenmann, 1903 (Teleostei: Characiformes: Serrasalmidae). Vertebrate Zoology, 58(2): 173196. 